\title{
Determinants of Environmental Sustainability among Tertiary Students During the COVID-19 Pandemic
}

\author{
John Mark R. Asio ${ }^{1 *}$
}

${ }^{1}$ Gordon College, PHILIPPINES

*Corresponding Author: asio.johnmark@gmail.com

Citation: Asio, J. M. R. (2021). Determinants of Environmental Sustainability among Tertiary Students During the COVID-19 Pandemic. Aquademia, 5(2), ep21011. https://doi.org/10.21601/aquademia/11444

ARTICLE INFO

Received: 6 Sep. 2021

Accepted: 27 Oct. 2021

\begin{abstract}
This study aims to assess the determinants of environmental sustainability among students from a tertiary education institution in Central Luzon, Philippines, during the COVID-19 pandemic. This study used a descriptive-correlational research design with the online survey as the primary data gathering tool. A total of 136 students participated in the online survey using the convenience sampling technique due to restriction protocols implemented by the government authority. For the instrument of the study, the researcher adopted and modified a previous instrument to fit with the study's objectives. With the help of SPSS 23, the researcher computed and analyzed the gathered data using weighted mean, Pearson-r, and regression analysis as statistical tools. In general, the students were "very aware" of environmental sustainability. In addition, students "often" do waste and recycling activities, consume consciously, and save energy. Furthermore, statistical inferences revealed a weak - moderate positive correlation between waste and recycling activities, conscious consumption, energysaving awareness, and environmental sustainability. For the determinants, waste and recycling activities and energy-saving awareness provided substantial evidence to influence the students' environmental sustainability in the study. This study becomes a reference and basis for future research in the field of environmental sustainability.
\end{abstract}

Keywords: conscious consumption, COVID-19 pandemic, determinants, energy-saving, environmental sustainability, waste and recycling activities

\section{INTRODUCTION}

Environmental sustainability is an essential component of our biodiversity. Emphasizing simple things about the environment is vital. As per definition, Morelli (2011) provided a vivid understanding of environmental sustainability, which is gathering all resources and needs of the current and future generations without conceding the well-being of the ecosystems. Different studies on environmental sustainability vary from one case to another. For example, an environmental sustainability curve hypothesis (Sarkodie \& Strezov, 2018), measuring environmental sustainability performance (Sun et al., 2020), and models on consumers (Panda et al., 2020). These ideas provided issues and study gaps for other researchers to explore the other realms of sustainability. New techniques and technology helped a lot in advancing the ideas of sustainability, especially in the environment, from merely describing it from the sociological perspective to quantifying them statistically. Even the results and findings expanded exponentially due to the awareness and consciousness of the community.
On the other hand, other studies showed interest in using social media for environmental sustainability awareness (Hamid et al., 2017) or in identifying factors affecting the environmental habits of students (Chuvieco et al., 2018). Nevertheless, in the context of higher education institutions, assessment of sustainability indicators in universities became a trend already for the past decades (Adenle et al., 2021). Khan et al. (2020) showed that environmental awareness increases when sustainability awareness activities increase. But on a negative note, a study by Msengi et al. (2019) indicated that a minority of the college students knew what sustainability was, but a majority responded that it was important. In a similar study, a high percentage of students heard the term "sustainability," but they lack the knowledge towards it (Alsaati et al., 2020). These contrasting results regarding higher education students' ideas, concepts, and awareness regarding environmental sustainability intrigue the researchers since, the subject matter is common. Poor emphasis or focus on the application of the said concept contributes to the unfamiliarity of the fact about sustainability. Because we live in one of the most dangerous 
eras of our time due to abuse and exploitation of natural resources, public awareness is inevitable.

Regarding the ideas on environmental sustainability, the first that comes into mind is the waste and recycling activities and ideas. A related article by Ali and Anufriev (2020) showed that waste influences university environmental quality. Another study also showed that students from a university involve themselves related to environmental protection (like recycling materials) (Boca \& Saracli, 2019). From another study, Alsaati et al. (2020) observed poor involvement among the students in terms of recycling in their school. To add, Goldman et al. (2018) highlighted that students and the schools perceived recycling as a major channel for proenvironmental behavior. In this particular idea, waste and recycling are inevitable among students regardless of age, level, or year especially when they are in their respective schools. Thus, the current study hopes to provide further clarification and reference for the said concept but in a different scenario or setting. Thus, somehow the current study is different from those mentioned pieces of literature in terms of the outcome.

In the context of consumption of school materials among students, "green" is the new "in" in terms of consumption. In the study of Huang et al. (2017), they disclosed that green attitude, subjective norms, and behavioral control predict green consumption intention among college students. Also, a particular study by Mizrachi et al. (2018) showed that most university students prefer to read course materials in print. In contrast, Ahmad and Ariffin (2018) assessed the knowledge, attitude, and practices regarding sustainable consumption of students in Malaysia and yielded some interesting findings. In the perspective of Xu et al. (2019), the environmental attitude impacts the intention to purchase of respondents. Modernity, on the other hand, showed evidence of a positive effect on student consumption behavior (Aviani \& Hadinto, 2019). However, a study found that santri consumption behavior was wasteful (Rahmattullah \& Hildayati, 2020). In a different perspective, a study by Kuswanto and Anderson (2021) posited that the quality of academic services affects the consumer behavior of the student. In terms of consumption among college students, some various links and factors play in the idea of consuming school materials among students. Therefore, in the current study, the researcher intends to explore more on the reasons why tertiary students, for example, prefer printed materials rather than online materials or vice versa. Seemingly, multifactorial influences affect students in consuming environmental materials in school.

Concerns and issues also vary from one study to another when it comes to energy-saving awareness. Paco and Lavrador's (2017) study indicated a weak link between attitude, behavior, and energy saving. A related study about sustainable energy consumption in schools showed different attitudes, incentives, knowledge, and awareness (Dumciuviene et al., 2018). However, Sarkodie and Strezov (2018) highlighted that renewable energy plays an important role in environmental sustainability. With these perspectives, the consensus falls into the importance of saving energy and the different attitudes and behavior of respondents. Bearing that in mind, this important factor contributes essentially to sustainability in application to students in higher education.
From the local perspective, the country also shared some interesting literature worth mentioning. In a study, Tejedor et al. (2018) revealed some significant themes regarding green products from the perspective of graduate school students. They found some interesting features that might help other consumers like for instance, students. Punzalan (2020) also hypothesized in his study that the students' environmental awareness related significantly to environmental practice, thus recommending the development of environmental education programs related to environmental problems and sustainability principles. A similar study by Nunez and Clores (2017) disclosed that students have a moderate level of environmental literacy, knowledge, and behavior but a high environmental attitude and sensitivity. Another study by Punzalan et al. (2019) showed that students from urban schools have a higher level of environmental awareness, and students from rural schools divulged a very high level. In terms of solid waste management, Madrigal and Oracion (2017) revealed a very positive and commendable result from their study. Considering the following results and findings, students in higher education provided a variety of inconsistent responses. Various local authors provided a vivid perspective regarding environmental awareness among college students. With this in mind, the study intends to further explore beyond environmental awareness and dwell on sustainability.

Based on the different reviewed accounts and presentations of varying degrees of ideas about environmental sustainability, the researcher then decided to come up with this study. The rationale behind such is to identify and assess certain perspectives and the general opinion of college students coming from a local community institution during the time of the pandemic. As seen from previous papers especially in the local contexts, there is not much in the field of environmental sustainability which focuses on college students coming to the local higher education institution. Also, this study wants to find out which among the three given variables, namely waste and recycling activities, conscious consumption, and energy-saving awareness, affects environmental sustainability among students. Since the majority of the reviewed literature points out other factors, this study is different making it unique on its own. Thus, this study intends to do such a feat and deliver some interesting insights regarding the research topic together with its accompanying variables.

This study aims to assess the level of environmental sustainability awareness of students, waste and recycling activities, conscious consumption, and energy-saving awareness. In addition, it also wants to find out any association among the four variables involved in the study. Lastly, the most important of all, to know which variable influences the environmental sustainability awareness among students.

This study benefits the school, the students, the community, and other important stakeholders interested in an environmental sustainability perspective. At the same time, it adds up to the growing literature about sustainability in the environment. Finally, to become a baseline and source of reference for future researchers and academicians in the years to come. 


\section{METHODOLOGY}

\section{Research Design}

This study used a descriptive-correlational type of research with the online survey as the primary tool for data gathering. Such design applies to this study since it aims to analyze a particular phenomenon or characteristic of a certain population. A correlational research design assesses the relationships between and among variables (two or more) (Stangor \& Walinga, 2014). The current study tried to analyze the determinants of environmental sustainability among tertiary students during the COVID-19 pandemic, thus the research design used fits the description.

\section{Sample of the Study}

The target population of this study was college students from a tertiary institution in Central Luzon, Philippines. The sample of the study came from different colleges/departments and using a convenience sampling technique, 136 college students participated via an online survey. A convenience sampling technique, according to Elfil and Negida (2017), is a non-probability sampling where investigators consider subjects according to their availability and accessibility. Because of the pandemic, data gathering became challenging and made it difficult to achieve the desired number of samples for the study, thus convenience sampling applies to such a situation. The researcher emailed and reached out to 250 students however, not all participated due to certain reasons. This study commenced during the first semester of the academic year 2020-2021. The inclusion criteria include the following: (1) bona fide student of the local higher education institution where the study commenced, (2) currently enrolled in the said institution, and (3) has an institutional email address where the online survey can be sent. On the other hand, exclusion criteria include (1) former students of the institution that is not enrolled, (2) no institutional e-mail address available, and (3) no internet connection for online survey participation.

\section{Instrument of the Study}

The study used an adapted and modified instrument from the study of Eren and Yakub (2015), which comprises several parts. The first part includes the profile characteristics of the respondents. The second part was a series of statements about the sustainable environment awareness of students. The third part tackled the waste and recycling activities of the students. The fourth part tackled conscious consumption, and the last part is the energy-saving awareness of the students. The researcher validated the instrument first to see any misunderstood terms or words from several professionals. These professionals include a Science major instructor, a data analyst, a major language instructor, a seasoned researcher, and a biology instructor. After a series of revisions, the instrument ran a preliminary test to analyze its reliability. To test the reliability, the researcher did a Cronbach Alpha test. The overall coefficient of the test was .876 . The result is better than the benchmark score of .70 for the reliability and acceptability of the instrument.

\section{Data Analysis}

For the statistical inference of the study, this research used the Statistical Package for Social Sciences (SPSS) 23 software to analyze the gathered data. In particular, the data analyst used the following statistical tools: weighted mean for the responses of the student-respondents, Pearson-r for the relationship among the variable of the study, and regression analysis for the determinants of the sustainable environment awareness among students. For the students' answers, this study patterned their responses to a four-point Likert scale for each variable.

\section{RESULTS}

This study aims to assess the determinants of environmental sustainability awareness of students from a local higher education institution during the COVID-19 pandemic. The study found the following results as presented by each succeeding table.

Table 1 shows the sustainable environment awareness of students. As seen from the table, statement 2 got the highest weighted mean with 4.69 , which corresponds to the Likert scale interpretation of "extremely aware." However, it is statement 1 that got the lowest weighted mean score of 3.60 , which is parallel to "very aware" in the Likert scale interpretation. Overall, the average weighted mean for the sustainable environment awareness of students was 4.22, which concur a Likert scale interpretation of "very aware." This result only shows that students involved in this study are familiar with environmental sustainability aspects and ideas.

Table 2 indicates the responses of students in terms of waste and recycling activities. The table shows that statement 8 got the highest weighted mean score of 4.56, which translates to "every time" from the Likert scale interpretation. But statement 1 got the lowest weighted means score with 3.43, which corresponds to a Likert scale interpretation of "sometimes." In general, the overall average weighted mean for students' waste and recycling activities stands at 4.02, which generates a Likert scale interpretation of "often." This result only shows that students still observe the basic notion of waste segregation and recycling activities despite the pandemic.

Table 3 represents the conscious consumption of students. As indicated, statement 3 got the highest weighted mean of 4.46, which translates to a Likert scale interpretation of "often." Conversely, statement 5 got the lowest weighted mean score of 3.26 with a corresponding Likert scale interpretation of "often." The overall average weighted mean for the conscious consumption of students stands at 3.82, which is equivalent to an "often" in the Likert scale also. This result only shows that students are particularly conscious of the different school stuff that they need to consume since this affects their performances in various ways and means.

Table 4 shows the energy-saving awareness of students. As observed from the table, statement 3 got the highest weighted mean score of 4.79 , followed closely by statement 2 with a weighted mean score of 4.67. Their weighted means correspond to the Likert scale interpretation of "every time." 
Table 1. Environmental sustainability among students

\section{Statements}

Weighted mean

1) The work of governmental and non-governmental organizations of our country is sufficient for the environment.

2) Young people should have a good environmental awareness for a sustainable environment.

3) Students' attendance at any project or seminar to acknowledge environmental awareness.

4) The necessity for all students to take subjects related to environmental awareness.

5) I always show my best efforts to prevent pollution of the environment and show awareness.

6) I think the choice of public transport is important for a sustainable environment.

7) The necessity for a sustainable environment to get your bills electronically.

8) Promotions of renewable energy resources are necessary for a sustainable environment.

9) I see that energy saving is important for a sustainable environment.

10) Recycling waste is important for the protection of the environment and natural resources.

11) The collection of waste in separate dustbins is important for a sustainable environment.

12) Enough separate collection dustbins (plastic, metal, etc.) in the institution's buildings.

Average weighted mean

Avend: $1.00-1.49=$ Not at

3.60

4.69

3.73

4.50

4.31

4.20

3.90

4.12

4.58

4.67

4.67

3.65

4.22

Very aware

Very aware

Interpretation

Very aware

Extremely aware

Very aware

Extremely aware

Very aware

Very aware

Very aware

Very aware

Extremely aware

Extremely aware

Extremely aware

Very aware

Table 2. Waste and recycling activities of students

\begin{tabular}{lcc}
\hline Statements & Weighted mean & Interpretation \\
\hline 1) I throw the used batteries in waste collection boxes. & 3.43 & Sometimes \\
\hline 2) I use rechargeable batteries instead of disposable batteries. & 3.93 & Often \\
\hline 3) I prefer to use long-lasting products for a sustainable environment instead of disposable ones. & 4.38 & Often \\
\hline 4) I avoid using plastic bags or packages. & 3.56 & Often \\
\hline 5) I use easily soluble bags rather than plastic bags. & 3.67 & Often \\
\hline 6) I pay attention to water consumption when using the sink and toilet. & 4.42 & Often \\
\hline 7) I try to protect the environment by using the least number of paper towels. & 4.04 & Often \\
\hline 8) I throw the garbage into dustbins before leaving the place and not leaving any trash around. & 4.56 & Everytime \\
\hline 9) I throw the plastic, metal, and paper to separate recycling boxes or bins. & 4.21 & Often \\
\hline Average weighted mean & $\mathbf{4 . 0 2}$ & Often \\
\hline
\end{tabular}

Legend: $1.00-1.49$ = Never; $1.50-2.49$ = Rarely; $2.50-3.49$ = Sometimes; $3.50-4.49$ = Often; 4.50-5.00 = Everytime

Table 3. Conscious consumption of students

Statements

1) I reuse the paper of lecture notes.

2) I take print on both sides of a paper.

3) I did check the preview of the document on the computer before printing.

4) I often sent an email instead of a hard copy output.

5) I prefer to read the document on the computer instead of taking its print on paper.

Average weighted mean

Legend: $1.00-1.49$ = Never; $1.50-2.49$ = Rarely; $2.50-3.49$ = Sometimes; $3.50-4.49$ = Often; 4.50-5.00 = Everytime

\begin{tabular}{cc} 
Weighted mean & Interpretation \\
\hline 4.03 & Often \\
\hline 3.52 & Often \\
\hline 4.46 & Often \\
\hline 3.82 & Often \\
\hline 3.26 & Often \\
\hline 3.82 & Often
\end{tabular}

Table 4. Energy saving awareness of students

Statements

1) To prevent unnecessary energy use, I use light and electric devices only when needed.

2) I keep my computer and printer off when I am not using them to save energy.

3) When I am leaving a room/place, I check if there is anyone to close the lights

Average weighted mean

Legend: $1.00-1.49$ = Never; $1.50-2.49$ = Rarely; $2.50-3.49$ = Sometimes; $3.50-4.49$ = Often; 4.50-5.00 = Everytime

\begin{tabular}{cc} 
Weighted mean & Interpretation \\
\hline 4.34 & Often \\
\hline 4.67 & Every time \\
\hline 4.79 & Every time \\
\hline $\mathbf{4 . 6 0}$ & Everytime \\
\hline
\end{tabular}

On the other hand, statement 1 got the lowest weighted mean score with 4.34, which equals a Likert scale interpretation of "often." To sum, the average weighted mean score was 4.60 , which translates to "every time" in the Likert scale interpretation. The result only means that students comply with all of the necessary concepts to save energy to some extent in terms of energy-saving awareness.

Table 5 presents the correlation matrix between energysaving awareness, conscious consumption, waste, and recycling activities, and sustainable environment awareness of students. Results of the correlation analysis revealed that the three primary variables of the study correlated positively and significantly to the environmental sustainability awareness of

students. The study obtained coefficients .412 for energysaving awareness, .343 for conscious consumption, and .406 for waste and recycling activities. All of their coefficients are lower than the alpha significance level set at .05. The findings indicate that, in general, the higher the energy-saving awareness, conscious consumption, and waste and recycling activities, the higher the sustainable environment awareness. Conversely, the lower the awareness on energy saving, conscious consumption, and waste and recycling activities, the lower the awareness of sustainable environment among students. 
Table 5. Correlation matrix among the four variables

\begin{tabular}{|c|c|c|c|c|}
\hline Variables & 1 & 2 & 3 & 4 \\
\hline 1) Energy saving awareness & 1 & & & \\
\hline 2) Conscious consumption & $\begin{array}{c}.355^{* * *} \\
.000 \\
\end{array}$ & 1 & & \\
\hline 3) Waste and recycling activities & $\begin{array}{l}.532^{* * * *} \\
.000\end{array}$ & $\begin{array}{l}.372^{* * * *} \\
.000\end{array}$ & 1 & \\
\hline 4) Environmental sustainability & $\begin{array}{l}.412^{* * * *} \\
.000\end{array}$ & $\begin{array}{c}.343^{* * * *} \\
.000\end{array}$ & $\begin{array}{c}.406 * * \\
.000\end{array}$ & 1 \\
\hline
\end{tabular}

** $p<.001$

Table 6. Determinants of environmental sustainability awareness among students

\begin{tabular}{lccccc}
\hline \multirow{2}{*}{ Model } & \multicolumn{2}{c}{ Unstandardized coefficients } & Standard coefficients & \multirow{2}{*}{ t } & Sig. \\
\cline { 2 - 5 } & $\mathbf{B}$ & Std.error & Beta & & 5.761 \\
\hline (Constant) & 1.764 & .306 & .202 & .000 \\
\hline Energy saving awareness & .162 & .064 & .137 & $2.556^{*}$ & .012 \\
\hline Conscious consumption & .095 & .054 & .399 & .758 & .081 \\
\hline Waste and recycling activities & .334 & .067 & $4.980^{*}$ & .000 \\
\hline
\end{tabular}

Note: $F(3,132)=23.100 ; p<.05 ; \mathrm{R}^{2}=.344$

The study subjected the data to regression analysis to determine the extent of influence of the variables on the awareness of sustainable environment among studentrespondents. Table 6 displays the result of the regression analysis.

The result of the analysis revealed that waste and recycling activities and energy-saving awareness recorded B coefficients with associated probability values lower than the alpha level of significance of .05 . These findings mean that waste and recycling activities and energy-saving awareness were significant determinants of sustainable environment awareness among students. A closer look at the obtained B coefficients says that in every unit increase in waste and recycling activities and energy-saving awareness could generate a .334 and .162 increase in the environmental sustainability awareness among students.

In general, other factors also correlated positively with sustainable environment awareness but not to a significant extent. These findings mean that the conscious consumption of students also accounts for environmental sustainability awareness.

The findings indicate that the three variables formed a very significant set of determinants on environmental sustainability awareness. The analysis of variance revealed an F-ratio of 23.100 , which corresponds to a probability value much lower than the alpha significance level of .05 . This result means that the three variables, namely energy-saving awareness, conscious consumption, and waste and recycling activities, formed a significant set of predictors in determining the environmental sustainability awareness of students.

\section{DISCUSSION}

This study aimed to assess the college students' environmental sustainability awareness and its determinants. Based on the study results, the researcher deduced the following significant findings in the study. First, the result of the environmental sustainability awareness of students was commendable. The study found that the student respondents were "very aware" of environmental sustainability. This result is a good sign since the institution employs measures and other important aspects of environmental practices that help everyone. This result is the opposite of the studies of Msengi et al. (2020) and Alsaati et al. (2019), wherein a minority of the students have some ideas regarding sustainability or lack knowledge about it. Next, when it comes to students' waste and recycling activities, the study showed that studentrespondents "often" exercise such practices. Since the school has a policy about solid waste management and other pertinent activities related to recycling, students value the importance of proper waste disposal and waste recycling to some extent. A study by Dolipas et al. (2020), however, showed quite the opposite. Their study found that, generally, students have very low levels of compliance on waste segregation. But the study of Lalamonan and Comighud (2020) showed parallel results with the current study wherein they disclosed that respondents in their study have a very high level of awareness in solid waste management. In the context of the conscious consumption of students, the study found that respondents are "often" conscious about their consumption, especially in their school needs. Students tend to save as much in materials like paper, printing, and other pertinent school matters that aid them in learning. Mizrachi et al. (2018) also showed a different concept of utilizing school materials, as students prefer printed materials. In addition, Xhang and Pan (2021) showed that COVID-19 affected college students who have lower than before consumption levels. In the study, students check the print materials before printing. This finding gives them an estimate of the cost of printing and tries to weigh things up. Finally, in terms of energy-saving awareness, the study also found that students practice this "every time." Since energy is also essential for learning because of the leisure and conduciveness it provides for students, saving efforts is a must. In a related study, Zhao et al. (2019) revealed that the majority of the students thought that is very necessary to save energy. A similar study also divulged that students have appreciable levels of energy efficiency awareness and are willing to support energy wastage reduction (Twumasi et al., 2017).

Statistical inferences of the study showed significant relationships among the four variables. This result means that energy-saving awareness, students' conscious consumption, 
and waste and recycling activities are associated significantly with students' environmental sustainability awareness. According to the study of Whitley et al. (2018), in environmental decision-making, one's values are critical, and it matters. But different values are associated with different behaviors among individuals. Although some related papers regarding the impact of the COVID-19 pandemic on environmental sustainability have positive and negative effects (Abubakar et al., 2021; Praveena \& Aris,2021; Rume \& Islam, 2020), the current study generally fall into the positive. Since the results imply a high level of awareness and knowledge from the students, it shows an affirmative connection to the mentioned studies.

\section{CONCLUSIONS}

Based on the preceding results of the study, the researcher concludes the following as a result of this. The study found that respondents are very aware of environmental sustainability. As well as doing waste and recycling activities, conscious consumption, energy-saving practices. Statistical analysis showed an association between environmental sustainability, waste and recycling activities, conscious consumption, and energy-saving awareness. Finally, to determine the factors that influence environmental sustainability among college students, the study found that waste and recycling activities and energy-saving awareness yielded significant results.

From these results, the researcher provided evidence in strengthening the environmental sustainability perspectives of college students, as well as its vital role in molding and developing the attitude and behavior towards waste and recycling, conscious consumption, and energy-saving practices. The results further offer some areas of emphasis to enhance and promote environmental consciousness among students even in tertiary education to maintain, help and protect the environment. The educational institution also benefits from the right attitude and behavior of students because of the pro-environment ideas and concepts which help the community in becoming environmentally sustainable in the future as well.

\section{Limitation of the Study}

This study also contains certain limitations just like any other research paper available for reading. Therefore, the researcher proposes the following for future researchers and other enthusiasts to help improve their manuscripts and explore other avenues that this paper was not able to present.

Since the paper was prepared during the pandemic, the replication of its contents depends on the situation for the next couple of years. Thus, the contents change so do the results. The research objectives/ aims/ purpose should focus more on the impact of a pandemic on environmental sustainability. For the scope of the study, future research can also consider not only tertiary institutions but also the secondary and even the primary ones all in one study. In terms of data collection, this study only tackled a single institution, therefore, future researchers must explore more by adding more schools. Also, it is equally important to use a sound sampling technique (a probability sampling technique) to obtain the best samples for the study. The research design also needs to improve, instead of simply using quantitative research, the researcher recommends using a mixed-method type of research as well to explore deeper. Statistical analysis can also go beyond using structural equation modeling (SEM) to further justify the links and create an environmental sustainability model in the future.

Author contributions: All co-authors have involved in all stages of this study while preparing the final version. They all agree with the results and conclusions.

Funding: No external funding is received for this article.

Declaration of interest: The authors declare that they have no competing interests.

Ethics approval and consent to participate: Not applicable.

Availability of data and materials: All data generated or analyzed during this study are available for sharing when appropriate request is directed to corresponding author.

\section{REFERENCES}

Abubakar, L., Salemcity, A. J., Abass, O. K., \& Olajuyin, A. M. (2021). The impacts of COVID-19 on environmental sustainability: A brief study in world context. Bioresource Technology Reports, 15, 100713. https://doi.org/10.1016/ j.biteb.2021.100713

Adenle, Y. A., Chan, E. H. W., Sun, Y., \& Chau, C. K. (2021). Assessing the relative importance of sustainability indicators for smart campuses: A case f higher education institutions in Nigeria. Environmental and Sustainability Indicators, 9, 100092. https://doi.org/10.1016/j.indic.2020. 100092

Ali, E. B., \& Anufriev, V. P. (2020). Towards environmental sustainability in Russia: Evidence from green universities. Heliyon, 6(8), e04719. https://doi.org/10.1016/ j.heliyon.2020.e04719

Alssati, T., El-Nakla, S., \& El-Nakla, D. (2020). Level of sustainability awareness among university students in the eastern province of Saudi Arabia. Sustainability, 12(8), 3159. https://doi.org/10.3390/su12083159

Aviani, E., \& Hardinto, P. (2019). The effect of modernity, economic literacy, and social environment on consumption behavior of senior high school students. Classroom Action Research Journal, 3(3), 102-109.

Boca, G. D., \& Saracli, S. (2019). Environmental education and student's perception, for sustainability. Sustainability, 11(6), 1553. https://doi.org/10.3390/su11061553

Chuvieco, E., Burgui-Burgui, M., Da Silva, E. V., Hussein, K., \& Alkaabi, K. (2018). Factors affecting environmental sustainability habits of university students: Intercomparison analysis in three countries (Spain, Brazil, and UAE). Journal of Cleaner Production, 198, 1372-1380. https://doi.org/10.1016/j.clepro.2018.07.121

Dolipas, B. B., Ramos, J. L., Alimondo, M. S., Ocampo, P. S., \& Fulwani, D. L. A. (2020). Awareness and compliance on waste segregation: Implication to a waste management program in a university. Athens Journal of Sciences, 7(2), 6776. https://doi.org/10.30958/ajs.7-2-1 
Dumciuviene, D., Cibinskiene, A., Melenhorst, M., \& Novak, J. (2018). Determinant of sustainable energy consumption in schools. Proceedings, 2(22), 1382. https://doi.org/ $10.3390 /$ proceedings 2221382

Elfil, M., \& Negida, A. (2017). Sampling methods in clinical research; an educational review. Emergency (Tehran), 5(1), e52.

Goldman, D., Ayalon, O., Baum, D., \& Weiss, B. (2018). Influence of 'green school certification' on students' environmental literacy and adoption of sustainable practice by schools. Journal of Cleaner Production, 183, 1300-1313. https://doi.org/10.1016/j.jclepro.2018.02.176

Hamid, S., Ijab, M. T., Sulaiman, H., Anwar, R. Md., \& Norman, A. A. (2017). Social media for environmental sustainability awareness in higher education. International Journal of Sustainability in Higher Education, 18(4), 474-491. https://doi.org/10.1108/IJSHE-01-2015-0010

Huang, C.-H., Huang, Y.-C., Jin, H., Lin, M.-C., Wu, Y.-P., \& Lee, L. (2017). An investigation of college students' green consumption behavior in China. International Journal of eEducation, e-Business, e-Management and e-Learning, 7(4), 280-286. https://doi.org/10.17706/ijeeee.2017.7.4.280-286

Khan, U., Haque, M. I., \& Khan, A. M. (2020). Environmental sustainability awareness in the Kingdom of Saudi Arabia. Journal of Asian Finance, Economics, and Business, 7(9), 687695. https://doi.org/10.13106/jafeb.2020.vol7.no9.687

Kuswanto, K., \& Anderson, I. (2020). Effect of service quality and motivation on the consumption behavior of students in academic services. International Journal of Evaluation and Research in Education, 10(1), 86-96. https://doi.org/ 10.11591/ijere.v10i1.20794

Lalamonan, E. N., \& Comighud, S. M. (2020). Awareness and implementation of solid waste management (SWM) practices. IJRDO - Journal of Educational Research, 5(5), 1143. https://ijrdo.org/index.php/er/article/view/3694

Madrigal, D. V., \& Oracion, E. G. (2017). Solid waste management awareness, attitude, and practices in a Philippine Catholic higher education. Recoletos Multidisciplinary Research Journal, 5(2), 44-57. https://doi.org/10.32871/rmrj1705.02.04

Mizrachi, D., Salaz, A. M., Kurbanoglu, S., Boustany, J., on behalf of the ARFIS Research Group. (2018). Academic reading format preferences and behaviors among university students worldwide: A comparative survey analysis. PLoS ONE, 13(5), e0197444. https://doi.org/10.1371/journal.pone.0197444

Morelli, J. (2011). Environmental sustainability: A definition for environmental professionals. Journal of Environmental Sustainability, 1(1), Art. 2. https://doi.org/10.14448/ jes.01.0002

Msengi, I., Doe, R., Wilson, T., Fowler, D., Wigginton, C., Olorunyomi, S., Banks, I., \& Morel, R. (2019). Assessment of knowledge and awareness of "sustainability" initiatives among college students. Renewable Energy and Environmental Sustainability, 4, 6. https://doi.org/10.1051/ rees/2019003
Nunez, M. B., \& Clores, M. A. (2017). Environmental literacy of K-10 student completers. International Journal of Environmental \& Science Education, 12(5), 1195-1215.

Paco, A., \& Lavrador, T. (2017). Environmental knowledge and attitudes and behaviors towards energy consumption. Journal of Environmental Management, 197, 384-392. https://doi.org/10.1016/j.jenvman.2017.03.100

Panda, T. K., Kumar, A., Jakhar, S., Luthra, S., Garza-Reyes, A., Kazancoglu, I., \& Nayak., S. S. (2020). Social and environmental sustainability model on consumers' altruism, gree purchase intention, green brand loyalty, and evangelism. Journal of Cleaner Production, 243, 118575. https://doi.org/10.1016/j.clepro.2019.118575

Praveena, S. M., \& Aris, A. Z., (2021). The impacts of COVID19 on the environmental sustainability: A perspective from the Southeast Asian region. Research in Environmental Planning and Management, 28, 63829-63836. https://doi.org/10.1007/s11356-020-11774-0

Punzalan, C. H. (2020). Evaluating the environmental awareness and practices of senior high school students: Basis for environmental education program. Aquademia, 4(1), ep20012. https://doi.org/10.29333/aquademia/8219

Punzalan, C. H., Signo, C. M. C., Signo, T. C., \& Marasigan, A. C. (2019). Environmental awareness of selected urban and rural high school students in the Philippines. Journal on School Educational Technology, 15(2), 15-25. https://doi.org/10.26634/jsch.15.2.16664

Rahmattullah, M., \& Hildayati, (2020). Consumption behavior of Santri in Islamic boarding school (study at Darussalam Martapura Islamic Boarding School). Advances in Social Science, Education and Human Research, 525, 218-222. https://doi.org/10.2991/assehr.k.210222.034

Rume, T., \& Islam, S. M. D.-U. (2020). Environmental effects of COVID-19 pandemic and potential strategies of sustainability. Heliyon, 6(9), e04965. https://doi.org/10.1016/j.heliyon.2020.e04965

Sarkodie, S. A., \& Strezov, V. (2018). An empirical study of the environmental Kuznets curve and environmental sustainability curve hypothesis for Australia, China, Ghana, and the USA. Journal of Cleaner Production, 201, 98110. https://doi.org/10.1016/j.jclepro.2018.08.039

Stangor, C., \& Walinga, J. (2014). Introduction to psychology 1st Canadian edition. BCcampus.

Sun, H., Mohsin, M., Alharthi, M., \& Abbas, Q. (2020). Measuring environmental sustainability performance of South Asia. Journal of Cleaner Production, 251, 119519. https://doi.org/10.1016/j.clepro.2019.119519

Tejedor, A. Z., Nugal, C. A., \& Amparado, M. A. P. (2018). Green products from the lens of graduate school students. International Journal of Social Sciences \& Educational Studies, 5(1), 1-6. https://doi.org/10.23918/ijsses.v5i1p1

Twumasi, E., Frimpong, E. A., Kemausuor, F., Appiah, D. O., \& Okyere, P. Y. (2017). Energy efficiency awareness and preparedness among students. 2017 IEEE PES PowerAfrica, 456-461.

https://doi.org/10.1109/PowerAfrica.2017.7991268 
Whitley, C. T., Takahashi, B., Zwickle, A., Besley, J. C., \& Lertprachya, A. P. (2018). Sustainability behaviors among college students: An application of the VBN theory. Environmental Education Research, 24(2), 245-262. https://doi.org/10.1080/13504622.2016.1250151

Xu, L., Prybutok, V., \& Blankson, C. (2019). An environmental awareness purchasing intention model. Industrial Management \& Data Systems, 119(2), 367-381. https://doi.org/10.1108/IMDS-12-2017-0591
Zhang, Q., \& Pan, H. (2021). The influence of college students' consumption concept and behavior under the background of normalization of Novel Coronavirus Pneumonia. International Journal of Science, 8(3), 164-170.

Zhao, S., Song, Q., \& Wang C. (2019). Characterizing the energy-saving behaviors, attitudes, and awareness of university students in Macau. Sustainability, 11(22), 6341. https://doi.org/10.3390/su11226341 